AN INTERNATIONAL JOURNAL

\title{
Physical and Biological Dosimetry for Risk Perception in Radioprotection
}

\author{
Ademir Amaral ${ }^{*}$ \\ Grupo de Estudos em Radioproteção e Radioecologia - GERAR; Departamento de Energia Nuclear; Universidade \\ Federal de Pernambuco; Av. Prof. Luiz Freire, 1000; 50740-540; amaral@.ufpe.br; Recife - PE - Brasil
}

\begin{abstract}
The increase in ionizing radiation (IR) applications, especially nuclear, has been followed by the growth of public concern for the potential associated risks. The public's perception of such risks is often based on the philosophy that IR is harmful at any exposure level. On the other hand, although radiation workers have knowledge about the nature of $I R$ and its potential health effects, the relationship between absorbed dose and risk is not well understood, principally for low doses. This report presents an overview of physical and biological dosimetry as complementary methodologies, as well as their possible contribution for improving risk perception in radioprotection.
\end{abstract}

Key words: Biodosimetry, Physical Dosimetry, Radioprotection, Public perception

\section{INTRODUCTION}

In 1895, Wilhelm Roentgen's discovery of X-rays was rapidly followed by the enthusiastic use of ionizing radiation (IR), especially for medical purposes. One year later, another landmark in the history of applications of ionizing radiation in human life appeared when the physicist Henri Becquerel discovered the "uranic rays". However, the initial lack of knowledge about the physical, chemical and biological phenomena involved in the interactions of IR with matter was responsible for deaths among the pioneering radiation workers and exposed patients (Kathren, 1962; Caufield, 1990). In 1928, nearly 30 years after Roentgen and Becquerel's discoveries, several recommendations for radiation safety were provided in the second meeting of the International Congress of Radiology, together with the foundation of the International Committee on x-Ray and Radium Protection. The latter became the well-known International Commission on Radiological Protection - ICRP (Stannard and Baalman, 1988; ICRP, 2000).

The importance of radiation protection programs has grown as a result of the increase in applications employing ionizing radiation as much as the public interest in the potential risks associated with their use.

Today, everyone agrees that knowledge about the complex biochemical and biophysical radiation processes at the cellular and molecular level, as well as the technology for safe use of ionizing radiation, has been improved. However, the public perception of radiation risks is generally based on the philosophy that IR is harmful regardless of how small the exposure. This scenario is a result of

\footnotetext{
* Author for correspondence
} 
psychological effects of the A-bomb used in Hiroshima and Nagasaki during the World War II and, more recently, the Chernobyl accident (Tubiana et al., 1996; UNSCEAR, 2000).

The risk perception, a subjective view of hazard, depends on knowledge of the nature of IR, its potential health effects and the mechanisms employed to predict them. In this context, physical and biological dosimetries are the main tools for collective and individual monitoring. The purpose of this article is to present a brief review of physical and biological dosimetry and their complementary use for improving the risk perception on radioprotection.

\section{PHYSICAL DOSIMETRY}

Absorbed dose, the amount of energy imparted to matter by IR per unit of mass, is the fundamental physical quantity for evaluating the potential biological response resulting from exposure to radiation. In SI, the unit of absorbed dose is expressed in grays $\left(1 \mathrm{~Gy}=1{\mathrm{~J} . \mathrm{kg}^{-1}}^{-1}(\mathrm{ICRP}, 1991)\right.$. The concept of absorbed dose has some limitations for evaluating biological effectiveness of exposure to radiation. For example, the pattern of energy deposition in living tissues, at the cellular level, varies according to the type of IR. Equal absorbed doses from different forms of radiations (such as $\mathrm{X}$ and $\gamma$ rays; electrons, protons, neutrons and $\alpha$ particles), do not imply the same level of biological response. To contrast biological effectiveness among the different forms of IR, relative biological effectiveness (RBE) was defined as the ratio of cumulative dose of a reference radiation (generally, $250 \mathrm{kVp} \mathrm{X}$-rays) with respect to cumulative absorbed dose of a test radiation to produce a specific biological effect.

To regulate the exposure of workers and the public at large, two derived dose quantities are suggested by ICRP (ICRP, 1991): equivalent and effective doses, both of which are expressed in sievert (Sv) to distinguish them from absorbed dose in grays (Gy).

For a particular tissue, the quantity equivalent dose $\left(\mathbf{H}_{\mathrm{T}}\right)$ is defined as:

$$
\mathbf{H}_{\mathrm{T}}=\sum_{R} \mathbf{w}_{\mathbf{R}} \mathbf{D}_{\mathrm{T}, \mathbf{R}}
$$

Where,

$\mathbf{w}_{\mathbf{R}}=$ radiation weighting factor for a type of radiation $\mathbf{R}$ and

$\mathbf{D}_{\mathbf{T}, \mathbf{R}}=$ absorbed dose in a tissue $\mathbf{T}$ as a result of to radiation exposure $\mathbf{R}$.

On the other hand, effective dose (E) was defined to take into account the contribution of all irradiated tissues and organs to the health detriment (ICRP 1991; ICRP, 1992). The effective dose is defined as:

$$
\mathbf{E}=\sum_{T} \mathbf{w}_{\mathbf{T}} \mathbf{H}_{\mathbf{T}}
$$

with

$\mathbf{w}_{\mathbf{T}}=$ tissue weighting factor, which represents the proportionate contribution of tissue $\mathbf{T}$ to the whole body risk.

Effective dose was introduced to represent the longterm risk of harm from radiation exposure, in particular the risk of radioinduced cancer.

\section{Recommended Dose Limits}

Knowledge of dose levels in radiation protection is an important step for risk assessment. Thus, to restrict the exposure to ionizing radiation, international authorities on radiation safety recommend dose limits to workers and members of the general public (IAEA, 1990; ICRP, 1991; CEU, 1996).

ICRP recommends an annual effective dose limit of $1 \mathrm{mSv}$ to members of the general public. However, a higher dose may be accepted, if necessary, provided the average over 5 years does not exceed $1 \mathrm{mSv}$. This dose limit is very low when compared with the world mean effective dose, i.e. $2.4 \mathrm{mSv}$, from natural background radiation (UNSCEAR, 1993). Several studies have failed to correlate natural background radiation levels and cancer incidence, even in regions with experimentally high natural background such as areas of India, and China (Luxin et al., 1990; Nambi and Soman, 1987). 
For dose limits in occupational exposure, ICRP recommends $20 \mathrm{mSv}$ per year, averaged over a defined period of 5 years, with the restriction that the absorbed dose should not exceed $50 \mathrm{mSv}$ in a single year.

The continuous changes in recommendation on dose limits have contributed to the philosophy that ionizing radiation is harmful at any dose (the linear no-threshold concept). As a result, generally, individuals believe that they are exposed to more serious radiation risks than they really are. For example, risk estimation cannot be obtained from epidemiological studies for very low doses such as those associated with nuclear medicine diagnoses. Doses below $200 \mathrm{mSv}$ are considered as low doses (UNSCEAR, 1993). Experiments with cells and animals remain the best way to derive a relationship between low doses and biological effects (Overbeek et al., 1999). However, extrapolation from cellular or whole animal experiments is not straightforward because consideration needs to be given to a range of effectmodifying factors.

Dose rate (or fractionation) is another important variable to be taken into account to evaluate biological effects. All this suggests that more research needs to be done on radiation-induced biological effects to make possible more precise risk estimates.

Physical dosimetry is commonly performed by instruments that are sensitive to the physical effects of IR. In most cases involving real or suspected accidental exposure, however, people were not wearing a dosimeter and, as a result, physical dosimetry is not straightforwardly achieved. For such situations, the study of early biological effects induced by an exposure to IR has been proposed as either a complementary or an alternative method for dose assessment (Downing, 2000; Bonassi and Au, 2002).

\section{BIOLOGICAL DOSIMETRY}

\section{Physical Symptomatology}

Evaluation of given biological endpoints to a known or estimated absorbed dose can be used in retrospective investigation of individual exposure. Damages from the interaction of IR with the human body generally occur at local and systemic levels such as changes in enzymes or cell populations, leading in some cases to physical symptoms. The best-known symptoms are those related to the prodromal stage following an acute irradiation, such as nausea, vomiting, and diarrhea. The severity and duration of these symptoms are related to the dose and physical characteristics of the radiation. For example, from 1 to 2 Gy of gamma irradiation, nausea and vomiting appear within six hours after exposure (Roman et al., 1997; Lushbaugh et al., 1982). Another important clinical bioindicator is erythema, which also depends of the type of radiation and the skin condition, having a median dose estimate of 6 Gy necessary for its appearance. All these symptoms are important bioindicators in cases of investigation of accidental acute irradiation.

\section{Main hematological Dosimeters}

Peripheral blood lymphocytes are extremely sensitive to IR. Chromosome aberrations (CA) in human peripheral blood lymphocytes are the most extensively studied system (Bender, 1964; Bender et al., 1988; Lloyd et al., 2000). Having a half-life of about 3 years, blood lymphocytes are normally found at the quiescent $\mathrm{G}_{0}$ phase of the cell cycle, which makes analysis possible long after a real or suspected exposure (Ramalho et al., 1995). Some chromosome-type aberrations (such as dicentrics and rings) are generally considered to be specific to radiation exposure, although in certain circumstances, a few chemical agents can also induce them. Considering different populations, the spontaneous frequency of dicentrics does not vary significantly, being of the order of 1 per 2000 lymphocytes (Voisin, 1997; Bonassi \& Au, 2002). Several studies have shown no significant difference between in vivo with in vitro $\mathrm{CA}$ in blood lymphocyte yields as a result of exposure to IR (Dossou et al., 2000).

Dicentrics, rings and fragments are referred to as unstable CA because their persistence in the body declines with cell division cycles. Lymphocyte cells sustaining unstable chromosome lesions have a probability of surviving in each mitosis of about $50 \%$. On the other hand, stable translocations are preserved longer because they pass through cell divisions. Thus, translocations are better biomarkers for retrospective dose evaluation when there has been a long delay between exposure and blood sampling (Pala et al., 2001). 
In addition, micronuclei (MN), a kind of unstable CA byproduct, are cytoplasm chromatin masses that arise from centric or acentric products of damaged chromosomes. They have the appearance of small nuclei, in addition to the cell's nucleus (Uma Devi et al., 1998; IAEA, 2001), and they are identified during the division of mitogen-activated human lymphocytes by blocking cytokinesis (Uma Devi et al., 1998). Since the scoring of MN is more sensitive and faster than the scoring of CA, improvements in MN methodology for biodosimetry have been tested (IAEA, 2001).

To interpret the scoring of either $\mathrm{CA}$ or $\mathrm{MN}$ in terms of radiation dose, a calibration curve (frequency of CA or MN versus dose) is necessary. In fact, considering the radiosensitivity of lymphocytes in vitro and in vivo as being equal, the dose-effect relationship obtained after in vitro irradiation of blood can be used to estimate effects from an irradiation in vivo (IAEA, 2001). Comparing the two methods in terms of material, the requirements for implementing one or the other are almost identical. In terms of workload, the MN method is faster than that of chromosome aberrations.

\section{Measuring Protein Expression}

More recently, the advent of fluorescent techniques, particularly flow cytometry, opened new possibilities in terms of detection of intracellular bioindicators. IR can cause different injuries in DNA, and those injuries induce the expression of several proteins to repair such damages. Among the proteins expressed during the DNA repair process, p53 has an important role concerning the integrity conservation of the genome. This protein is found in the cytoplasm in reduced concentration and has a short average life. However, the expression of p53 protein is induced for a variety of physicochemical agents harmful to the DNA molecules, increasing the concentration and the average life of this protein and making its detection possible (Levine, 1997, Rössner Jr. et al., 2004). Thus, the correlation between the increasing p53 expression and the irradiation may constitute a fast and reliable method of individual monitoring in cases of accidental or suspected exposures to IR.

\section{CONCLUSION}

In response to radiation exposures, rapid and reliable dose estimates are crucial for risk assessments during investigation of real or suspected exposed victims. The employment of biodosimetry can represent more than a complementary methodology to physical dosimetry in individual monitoring. Knowledge about the quantity of absorbed dose, a number together with its unit, is certainly not sufficient to evaluate the risks associated with radiation exposure. In addition, the comparison between the changes in biological indicators as a result of an irradiation, with the same alterations caused by other physicochemical agents may be important for better understanding of radiation hazards and the risks associated with them. This will aid professionals, as well as laypeople, in a better observance of radioprotection practices.

\section{RESUMO}

O crescente aumento das aplicações das radiações ionizantes, em particular as radiações de origem nuclear, tem sido acompanhado pelo aumento do interesse público em relação aos riscos associados a essas aplicações. A percepção de tais riscos por parte da população é freqüentemente baseada na filosofia que a radiação ionizante é perigosa independentemente dos níveis de exposição. Por outro lado, apesar dos trabalhadores ocupacionalmente expostos terem conhecimento da natureza da IR e seus possíveis efeitos á saúde, a relação entre dose absorvida e risco não é bem entendida por estes, em particular para baixos valores de dose. Este artigo resume aspectos da dosimetria física e biológica como metodologias complementares na melhoria da percepção dos riscos em radioproteção.

\section{REFERENCES}

Bender, M. A. (1964), Chromosome aberrations in irradiated human subjects. Ann. NY Acad. Sci., 114, 249-25. 
Bender, M. A.; Awa, A. A.; Brooks, A. L.; Evans, H. J.; Groer, P. G.; Littlefield, L. G.; Pereira, C.; Preston, R. J. and Waschholz, B. W. (1988), Current status of cytogenetic procedures to detect and quantify previous exposures to radiation. Mutat. Res., 196, 103-159.

Bonassi, S. and Au, W. W. (2002), Biomarkers in molecular epidemiology studies for health risk prediction. Mutat. Res., 511, 73-86.

Caufield, C. (1990), Multiple exposures: chronicles of the radiation. Chicago : University of Chicago Press. pp. 304.

Council of the European Union (1996), Council Directive 96/29/Euratom of 13 May 1996 laying down basic safety standards for the protection of health of workers and the general public against the dangers arising from ionizing radiation. Official Journal of the European Communities, I.159, I-114.

Dossou, J.; Lartigau, E.; M'Kacher, R.; Légal, J. D.; Bridier, A.; Guichard, M.; Eschwege, F. and Parmentier, C. (2000), Biological dosimetry after total body irradiation (TBI) for hematologic malignancy patients. Int. J. Radiation Oncology Biol. Phys., 46 : (1), 123-129.

Downing, G. J. (2000), Biomarkers and surrogate endpoints in clinical research: definitions and conceptual model. In: Downing, G. J. (Ed.). Biomarkers and Surrogate Endpoints:Clinical Research and Applications. Amsterdam : Elsevier. pp. 1-9.

International Atomic Energy Agency (1990), Recommendations for safe use and regulation of radiation sources in industry, medicine, research, and teaching. Vienna, Austria. (IAEA Safety Series; 102).

International Atomic Energy Agency (2001), Cytogenetic Analysis for Radiation Dose Assessment. Vienna. (IAEA Technical Report Series; 405).

International Commission on Radiological Protection (1991), Recommendations of the International Commission on Radiological Protection, ICRP-60. Oxford : Pergamon Press.

International Commission on Radiological Protection (1992), Recommendations of the International Commission on Radiological Protection: User's Edition. Oxford : Pergamon Press.

International Commission on Radiological Protection (2000), Historique, politiques et méthodes de la CIPR. EDP Sciences. pp. 32.

Kathren, R. L. (1962), Early x-Ray protection in the United States. Health Phys, 8, 503-511.

Levine, A. J. (1997), P53, The cellular gate keeper for growth and division. Cell, 88, 323-331.
Lloyd, D. C.; Edwards, A. A.; Moquet, J. E. and Guerero-Carbajal, Y. C. (2000), The role of cytogenetics in early triage of radiation causalities. Appl. Rad. Isot., 52, 1107-1112.

Lushbaugh, C. C.; Hubner, K. F. and Fry, S. A. (1982), The impact of estimates of human radiation tolerance upon radiation emergency management. In: Symposium the Control of Exposure of the Public to Ionizing Radiation in the Event of Accidental Attack. National Council on Radiation Protection and Measurements. Washington, DC. Proceedings... Washington, DC.

Luxin, W.; Yongru, Z.; Zufan, T.; Weihui, H.; Deqing, C. and Yongling, Y. (1990), Epidemiological investigations of radiological effects in high background radiation areas of Yangjiang, China. J. Radiat. Res., 31, 119-136.

Nambi, K. S. V. and Soman, S. D. (1987), Environmental irradiation and cancer in India. Health Phys., 52, 653-657.

Overbeek, F. J.; Pauwels, E. K. J.; Bloem, J. L.; Camps, J. A. J. and Geleijns, J. (1999), Somatic effects in nuclear medicine and radiology. Appl. Rad. Isot., 50: 63-72.

Pala, F. S.; Moquet, J. E.; Edwards, A. A. and Lloyd, D. C. (2001), In vitro transmission of chromosomal aberrations through mitosis in human lymphocytes. Mutat. Res., 474, 139-146.

Ramalho, A. T.; Curado, M. P. and Natarajan, A. T. (1995), Lifespan of human lymphocytes estimated during a six year cytogenetic follow-up of individuals accidentally exposed in the 1987 radiological accident in Brazil. Mutat. Res., 331, 47-54.

Roman, V.; Fatome, M. and Kolodie, H. (1997), Accidental acute irradiation. In: Court, L. and Lallemand, A. (Eds.). Paris : L’Homme Blessé. pp. 105-106.

Rössner Jr., P.; Chvatalova, I.; Schmuczerova, J.; Milcova, A.; Rössner, P. and Sram, R. J. (2004), Comparison of p53 levels in lymphocytes and in blood plasma of nuclear power plant workers. Mutation Research, 556, 55-63.

Stannard, J. N. and Baalman Jr., R. W. (1988), Radioactivity and health: a history. Applied aspects, instrumentation, and conclusions. Columbus, $\mathrm{OH}$ : Battelle Press.

Tubiana, M.; Galle, P.; Schlumberger, M.; Cosset, J. M. and Bacher, P. (1996), Tchernobyl: le vrai, le faux et l'incertain. Paris : SFEN.

Uma Devi, P.; Satish Rao, B. S. and Kamath, R. (1998), A method to score micronuclei in vivo using cytochalasin B-induced cytokinesis block. Mutat. Res., 401, 33-37. 
United Nations Scientific Committee on the Effects of Atomic Radiation (2000), Sources, effects and risks of ionizing radiation. New York.

United Nations Scientific Committee on the Effects of Atomic Radiation (1993), Sources and effects of ionizing radiation. New York United Nations, Report to the General Assembly, with Scientific Annexes.
Voisin, P. (1997), Chromosome lesions as short and medium term biological indictor of acute irradiation. In: Court, L. and Lallemand, A. (Eds.). L'homme blessé. Paris. pp. 139-150. 